\title{
COMPARATIVE PHYTOCHEMICAL PROFILE AND ANTIOXIDANT PROPERTY OF BARK, FLOWERS AND LEAVES EXTRACTS OF SIMAROUBA GLAUCA
}

\author{
SAJEEDA N ${ }^{1,2}$, KOLGI RR ${ }^{1,3}$, SHIVAKUMARA SL ${ }^{1}$, SHIVARAJ $\mathbf{Y}^{2}$, KARIGAR CS $^{3 *}$ \\ ${ }^{1}$ Department of PG Studies and Research in Biochemistry, Tumkur University, Tumkur, Karnataka, India. ${ }^{2}$ Department of Chemistry \\ and Biochemistry, Government Science College, Bengaluru, Karnataka, India. ${ }^{3}$ Department of PG Studies and Research in Biochemistry, \\ Bangalore University, Bengaluru, Karnataka, India. Email: karigar@bub.ernet.in.
}

Received: 20 May 2019, Revised and Accepted: 29 June 2019

ABSTRACT

Objective: The current study was to evaluate and compare the phytochemical constituents and antioxidant activity of bark, flowers and leaves of the tree Simarouba glauca.

Methods: The solvent extraction of phytochemicals was carried out using Soxhlet apparatus with ethanol, chloroform, methanol, and water. The antioxidant property was determined by 2,2-Diphenyl-1-picrylhydrazyl, hydrogen peroxide free radical scavenging, reducing power assay, and nitric oxide radical scavenging assay using gallic acid and ascorbic acid as the standards.

Results: The extraction yield was found maximum in the water extract of flower $(3.7 \% \mathrm{w} / \mathrm{w})$. Qualitative and quantitative analysis of phytoconstituents showed that the highest amount of alkaloids and flavonoid content $(2.1 \% \mathrm{w} / \mathrm{w})$ and $(3.9 \% \mathrm{w} / \mathrm{w})$, respectively, was in the chloroform extract of the flower. Phenol and carbohydrate constituent was found to be highest in the methanol extract of leaves $2.5 \% \mathrm{w} / \mathrm{w}$ and $2.2 \% \mathrm{w} / \mathrm{w}$, respectively. The antioxidant assays showed that the bark possessed maximum antioxidant activity. The water extracts of S. glauca bark exhibited scavenging property $(90 \%)$ with an $\mathrm{IC}_{50}$ value $39.63 \mu \mathrm{g} / \mathrm{ml}$, and the least activity $(56 \%)$ was observed in the methanol extracts of leaves with an IC $\mathrm{C}_{50}$ value of $62.96 \mu \mathrm{g} / \mathrm{ml}$ of $S$. glauca.

Conclusion: The study concluded that the water extract of the bark is a potent antioxidant compared to leaves and flowers. Further, in vivo studies are essential to enumerate its medicinal use and prove its efficacy in therapeutic applications.

Keywords: Simarouba glauca, Solvent extraction, Phytochemical constituents, Antioxidant activity, In vitro methods.

(C) 2019 The Authors. Published by Innovare Academic Sciences Pvt Ltd. This is an open access article under the CC BY license (http://creativecommons. org/licenses/by/4. 0/) DOI: http://dx.doi.org/10.22159/ajpcr.2019.v12i9.34211

\section{INTRODUCTION}

Simarouba glauca DC, popularly known as "Laxmitaru or Paradise Tree" is an evergreen, edible oil tree incurring great interest as a promising energy crop and for providing therapeutic benefits [1]. This tree is a native of South and Central America, and it is now widely grown in the states of Karnataka, Tamil Nadu, Orissa, Kerala, and Maharashtra [2]. Among several benefits and widespread applications, this tree is becoming a tree of solace for many cancer patients in these states of India [3]. The specific name Glauca comes from the Greek word which means blossom intending bluish-green foliage [4]. This multipurpose tree grows to a height of 50 feet with 30 feet spread around, showcased with threeinch-long, shiny, and leathery leaflets which are reddish when young. Once fully grown, it produces a dense crown on top bearing tiny, inconspicuous, yellowish flowers, and tiny clusters of dark purple, oneinch-long, and edible fruits [5]. The leaves and bark extracts have been excessively used as hemostat antimalarial, antidysenteric, anthelmintic, antipyretic and anticancerous [6]. The chief components present in S. glauca that is promoting these properties are the quassinoids [7]. The quassinoids present in S. glauca are glaucarubin, glaucarubol, glaucarubolone, and the two esters of glaucarubolone, ailanthinone, and glaucarubinone [8]. The quassinoids isolated from the seeds have shown to be effective against $P$. falciparum culture $[9,10]$. Glaucarubin is found to contain antiamoebic and antiplasmodial activity. Thus, its extracts are commonly used as a medicine to treat gastrointestinal disorders and malaria $[9,11]$. Glaucarubinone isolated from this tree was found to be responsible for the antileukemic and cytotoxic activities in P388 lymphocytic leukemia model [12,13]. Quassinoids and alkaloids isolated have shown high cytotoxic effect and antimalarial activity. The cytotoxicity is related to the inhibition of protein synthesis $[14,15]$. In the year 1997, a U.S. patent was filed on Simarouba extract of water being able to produce a cosmetic or pharmaceutical product for healthy skin. Today, it is well known that the leaf, seed, bark, and fruit of $S$. glauca have great medicinal properties such as astringent, analgesic, emmenagogue, antiviral, antimicrobial, stomachic, and vermifuge [1,2].

The present study focused on the extraction of phytochemicals using ethanol, methanol, chloroform, and water from bark, flower, and leaves of $S$. glauca and to determine the antioxidant activity of the extracts.

\section{METHODS}

Sample collection

Dry leaves, bark, and flower of S. glauca were collected separately from the GKVK, University of Agricultural Sciences, Bengaluru. The plant specimen was authenticated from Regional Ayurveda Research Institute for Metabolic disorders, Ref no. RRCBI-mus215. The leaves, flowers and bark were separately washed thoroughly, shade dried at room temperature for 30-40 days. The dried plant samples were pulverized to a powder and stored separately for further analysis.

\section{Preparation of extracts}

$30 \mathrm{~g}$ of shade-dried powder of bark (N1), flowers (N2), and leaves (N3) of S. glauca was taken in a Soxhlet apparatus and subjected to the successive solvent extraction process in the order of their polarity. The solvents used were chloroform, ethanol, methanol, and water. The process of extraction using Soxhlet apparatus was carried out in a $250 \mathrm{ml}$ of each solvent separately. The apparatus carrying out the extraction was time framed for complete $48 \mathrm{~h}$ after which the solvent mixture was concentrated using a rotary vacuum evaporator [16]. The extracts obtained were 
kept in moisture free condition and the samples were used further for phytochemical analysis and to study the antioxidant activity.

\section{Chemicals and reagents}

All the organic solvents such as ethanol, chloroform and methanol were obtained from HiMedia, and distilled water was used during the extraction process. Phytochemical screening reagents such as hydrochloric acid $(\mathrm{HCl})$, Mayer's and Wagner's reagent, sulfuric acid (H2SO4), 0.1\% ferric chloride ( $\mathrm{FeCl} 3)$, lead acetate $(\mathrm{Pb}(\mathrm{C} 2 \mathrm{H} 3 \mathrm{O} 2) 2)$, Fehling's and Benedict's reagent, dil-ammonium hydroxide ( $\mathrm{NH} 4 \mathrm{OH})$, and sodium carbonate ( $\mathrm{Na} 2 \mathrm{CO} 3)$, antioxidant assay reagents such as 2,2-diphenyl-1-picryl hydrazyl (DPPH) were all procured from SigmaAldrich Chemical Company (St. Louis, MO, USA). 1\% hydrogen peroxide (H2O2), 0.1\% ethylenediaminetetraacetic acid (EDTA), potassium ferricyanide ( $\mathrm{K} 3[\mathrm{Fe}(\mathrm{CN}) 6), 2.5 \%$ trichloroacetic acid $(\mathrm{CCl} 3 \mathrm{COOH})$, $0.7 \%$ thiobarbituric acid, $0.05 \mathrm{~N}$ potassium hydroxide $(\mathrm{KOH}), 5 \mathrm{mM}$ sodium nitroprusside, $2.5 \mathrm{mM}$ phosphate buffer ( $\mathrm{pH}-7.4)$, and Griess reagent ( $1 \%$ sulfanilamide, $0.1 \% \mathrm{~N}$ 1-naphthylethylenediamine, and $2 \%$ orthophosphoric acid) were procured from Merck, India.

\section{Instrumentation}

The absorbance was read using the UV-visible absorption spectroscopy (UV-1800, Shimadzu, Japan). Roteva Equiptronics-Rota evaporator was used to evaporate the solvent under controlled condition.

\section{Phytochemical screening}

The phytochemical investigation for individual extracts of S. glauca was performed as per the standard protocols [17-19].

\section{Detection of alkaloids}

The $S$. glauca sample extracts were dissolved in a test tube containing dilute hydrochloric acid which was later filtered. This filtrate was collected and used to detect the presence of alkaloids through Mayer's test. The obtained yellow precipitate suggested the presence of alkaloids.

\section{Detection of flavonoids}

Lead acetate test: Extracts were treated with few drops of lead acetate solution. Formation of yellow colored precipitate indicated the presence of flavonoids.

The sulfuric acid test: Few drops of concentrated $\mathrm{H}_{2} \mathrm{SO}_{4}$ were added to the plant extracts which formed an orange coloration that evidenced the flavonoid content in them.

\section{Detection of steroids}

$2 \mathrm{ml}$ of acetic anhydride was taken and to this $5 \mathrm{mg}$ of plant extracts and $2 \mathrm{ml}$ of $\mathrm{H}_{2} \mathrm{SO}_{4}$ were added. The color changed from violet to bluish green which indicated the presence of the steroid.

\section{Detection of terpenoids}

Salkowski's Test: $5 \mathrm{mg}$ of the plant extracts individually were treated with $2 \mathrm{ml}$ of chloroform. $3 \mathrm{ml}$ of concentrated $\mathrm{H}_{2} \mathrm{SO}_{4}$ was added along the inner surface of a test tube that established a layer. The appearance of reddish-brown color suggested that the terpenoids are present in the extracts.

\section{Detection of anthraquinones}

Borntrager's Test: About $5 \mathrm{mg}$ of the plant extracts were treated with $10 \% \mathrm{HCl}$ and allowed to boil in a water bath for 2-3 min. This was later cooled and filtered. Equal quantity of chloroform was added to the filtrate and a few drops of $10 \%$ ammonia were added to the mixture and heated. The pink coloration that developed showed the presence of anthraquinones.

\section{Detection of phenols}

Ferric chloride test: $10 \mathrm{mg}$ of extracts were mixed with few drops of $\mathrm{FeCl}_{3}$ solution. Formation of bluish-black liquid showed the phenolic content in the plant extracts.
Lead acetate test: $10 \mathrm{mg}$ extracts were mixed with few drops of lead acetate solution. Formation of yellow-colored precipitate confirmed the phenolic group presence.

\section{Detection of saponins}

About $0.5 \mathrm{mg}$ of plant extracts were well stirred after adding $5 \mathrm{ml}$ of distilled water. The froth formation indicated the presence of saponins in the extracts.

\section{Detection of tannins}

About $0.5 \mathrm{mg}$ of the extract was diluted using distilled water and incubated in a water bath for a minute. The filtration process was carried out and $\mathrm{FeCl}_{3}$ solution was added to the filtrate. The appearance of a dark green color confirmed the presence of tannins.

\section{Carbohydrate tests}

Fehling's Test: Fehling's solution A and B were heated with the $1 \mathrm{ml}$ of the plant extracts, the reducing sugars eventually formed yellowish red colored cuprous oxide precipitate. Hence, the formation of the yellow or brownish-red colored precipitate confirmed the carbohydrates in them.

Benedict's test: Similar to Fehling's test, a free aldehyde group or a keto group present in the reducing sugars reduces the alkaline copper hydroxide to red-colored cuprous oxide. Thus, according to the concentration of sugars, yellowish-red to green color was developed. This confirmed the presence of carbohydrates.

\section{Tests for oil}

Grease spot test: About $0.5 \mathrm{mg}$ of the sample extract was put on pieces of paper and a greasy spot penetrating the paper was observed. This happened because lipid does not wet paper, unlike water proving the oil content in extracts.

\section{Quantitative phytochemical analysis Estimation of alkaloids}

$1 \mathrm{~g}$ of the plant extract was taken in a $250 \mathrm{ml}$ beaker and $200 \mathrm{ml}$ of $10 \%$ acetic acid in ethanol was added to it. This was covered and incubated for $4 \mathrm{~h}$ at room temperature. Later it was filtered and the plant extract was concentrated up to one-quarter of the initial volume. Ammonium hydroxide was introduced dropwise into the extract until the precipitation was complete. This solution was kept undisturbed and the precipitate was separated, washed using $\mathrm{NH}_{4} \mathrm{OH}$ and later filtered again. The residue showed the presence of the alkaloid which was weighed for quantification $[18,19]$.

\section{Estimation of flavonoids}

$1 \mathrm{~g}$ of plant extract was repeatedly extracted using $100 \mathrm{ml}$ of the $80 \%$ aqueous methanol. This mixture was filtered using a Whatman filter paper No. 1 and poured into a previously weighed beaker. The filtrate was heated on a water bath and evaporated to dryness, then weighed [20].

\section{Estimation of total phenols}

$1 \mathrm{~g}$ of the plant extracts were made to boil by adding $50 \mathrm{ml}$ of ether for $15 \mathrm{~min}$ for the extraction of the phenolic component. $5 \mathrm{ml}$ of the extract was measured and poured into a $50 \mathrm{ml}$ flask, and then $10 \mathrm{ml}$ of distilled water was added. $2 \mathrm{ml}$ of $\mathrm{NH}_{4} \mathrm{OH}$ solution and $5 \mathrm{ml}$ of pentanol (amyl alcohol) were added into the mixture. The samples were diluted up to $50 \mathrm{ml}$ and kept undisturbed for $30 \mathrm{~min}$ for bluish-black color development. The absorbance was read at $505 \mathrm{~nm}$ [21].

\section{Estimation of carbohydrates}

$100 \mathrm{mg}$ of sample extracts were hydrolyzed using hot water in a test tube filled with $5 \mathrm{ml}$ of $2.5 \mathrm{~N} \mathrm{HCl}$ for a period of $3 \mathrm{~h}$. Later, this was cooled at room temperature and solid $\mathrm{Na}_{2} \mathrm{CO}_{3}$ was added. The mixture was centrifuged, and the supernatant was separated and made up to $100 \mathrm{ml}$ using distilled water. $1 \mathrm{ml}$ of the diluted solution and $1 \mathrm{ml}$ of phenol were added followed by $5 \mathrm{ml}$ of $\mathrm{H}_{2} \mathrm{SO}_{4}$. The contents were mixed 
well and kept at room temperature for about $20 \mathrm{~min}$. The absorbance of the mixture was measured at $490 \mathrm{~nm}$ [22].

\section{Evaluation of antioxidant activity}

Antioxidant properties of the plant extracts of S. glauca were analyzed by conducting DPPH free radical scavenging assay, hydrogen peroxide assay reducing power, and nitric oxide (NO) assay as given below [23-29].

\section{DPPH radical scavenging assay}

DPPH assay was performed as per Rajakumar et al. (1994) method. $1.3 \mathrm{mg} / \mathrm{ml}$ DPPH was prepared in HPLC grade methanol of which $75 \mu \mathrm{l}$ of DPPH solution was utilized, and various concentrations $(6.25,12.5,50$, and $100 \mu \mathrm{g} / \mathrm{ml}$ ) of test solutions were prepared, and volume was made up to $3 \mathrm{ml}$ with HPLC grade methanol. All the plant extract samples were compared with the gallic acid which was used as the reference standard. The reaction mixture was well mixed and incubated at room temperature for $15 \mathrm{~min}$, and the absorbance was recorded at $510 \mathrm{~nm}$.

$\%$ Scavenged $[\mathrm{DPPH}]=[(\mathrm{AC}-\mathrm{AS}) / \mathrm{AC}] \times 100$

Where AC is the absorbance of the control and AS is the absorbance in the presence of the sample of extracts or standards. Gallic acid was used as standard $[23,24]$.

\section{Hydrogen peroxide scavenging assay}

A solution of hydrogen peroxide ( $4 \mathrm{mM})$ was prepared in phosphate buffer (pH 7.4). Extracts of concentrations $(6.25,12.5,50$, and $100 \mu \mathrm{g} / \mathrm{ml})$ in distilled water were added to a hydrogen peroxide solution $(0.6 \mathrm{ml}$ and $4 \mathrm{mM}$ ) and final volume was made up to $1.1 \mathrm{ml}$ with distilled water. The absorbance of hydrogen peroxide at $230 \mathrm{~nm}$ was determined $10 \mathrm{~min}$ later against a blank solution containing the phosphate buffer without hydrogen peroxide. The percentage of hydrogen peroxide scavenging of both the extracts and the standard compounds was calculated.

$\%$ Scavenged $\left[\mathrm{H}_{2} \mathrm{O}_{2}\right]=[(\mathrm{AC}-\mathrm{AS}) / \mathrm{AC}] \times 100$

Where AC is the absorbance of the control and AS is the absorbance in the presence of the sample of extracts or standards. Gallic acid was used as standard [25].

\section{Estimation of reducing power}

The reducing power of the plant extracts was determined by the method stated by Oyaizu et al. with slight modifications. The extracts were prepared at varied dilutions such as $6.25,12.5,50$, and $100 \mu \mathrm{g} / \mathrm{ml}$ and were added to a mixture of $2.5 \mathrm{ml}$ of $20 \mathrm{mM}$ phosphate buffer $\mathrm{pH} 6.6$ and $2.5 \mathrm{ml}(1 \% \mathrm{w} / \mathrm{v})$ potassium ferricyanide and were incubated at $50^{\circ} \mathrm{C}$ for a period of $30 \mathrm{~min} .2 .5 \mathrm{ml}$ of $(10 \% \mathrm{w} / \mathrm{v})$ trichloroacetic acid and $0.5 \mathrm{ml}$ of $(0.1 \% \mathrm{w} / \mathrm{v})$ ferric chloride were pipetted into the mixture and incubated again for $10 \mathrm{~min}$ at room temperature to obtain a green-colored complex. The absorbance of the color developed was measured at $700 \mathrm{~nm}$ using UV-visible spectrophotometer. The stronger absorbance indicated greater reducing power. Gallic acid was used as a positive reference standard $[26,27]$. The percentage of reducing activity was calculated using the formula.

$\%$ Scavenged $=[(\mathrm{AC}-\mathrm{AS}) / \mathrm{AC}] \times 100$

Where AC is the absorbance of the control and AS is the absorbance in the presence of the sample of extracts or standards.

\section{NO radical scavenging assay}

An aqueous solution of sodium nitroprusside at a physiological $\mathrm{pH}$ triggers the generation of nitrite oxide instantly which spontaneously binds with an oxygen molecule to produce nitrite ions, which can be detected at $550 \mathrm{~nm}$ by spectrophotometer after the addition of Griess reagent. Thus, sodium nitroprusside $(5 \mathrm{mM})$ prepared in standard phosphate buffer saline $(0.025 \mathrm{M}$ and $\mathrm{pH} 7.4)$ was incubated at $29^{\circ} \mathrm{C}$ for $3 \mathrm{~h}$ in the test tubes after the addition of varied concentration $(6.25,12.5$, 50 , and $100 \mu \mathrm{g} / \mathrm{ml}$ ) of $S$. glauca plant extracts in each of them. For the control, the equivalent volume of buffer was incubated in an identical manner without any extract. $1 \mathrm{ml}$ Griess reagent was added in each of the test samples after incubation and the absorbance of the solutions was measured at $550 \mathrm{~nm}$ spectrophotometrically against the blank solution. Ascorbic acid was used as a standard for comparison [28,29]. The free radical scavenging activity was determined by evaluating percentage inhibition as given below.

$\%$ Scavenged $[\mathrm{NO}]=[\mathrm{AC}-\mathrm{AS}) / \mathrm{AC}] \times 100$

Where AC is the absorbance of the control and AS is the absorbance in the presence of the sample of extracts or standards.

\section{RESULTS}

\section{Extraction yield}

The percentage yield obtained after the extraction procedure using Soxhlet apparatus is summarized in Table 1. The N1, N2, and N3 represent to the bark, flowers, and leaves of S. glauca, respectively. The solvents used for the extraction process are water, methanol, chloroform, and ethanol which are abbreviated as W, M, C and E respectively. The basic coloration of the extracts was in shades of green to brownish-black. The crude extract yield was found between $0.6 \%$ and $3.7 \% \mathrm{w} / \mathrm{w}$. The percentage yield of chloroform extract of bark and leaves was observed to be $2.4 \% \mathrm{w} / \mathrm{w}$ and $2.7 \% \mathrm{w} / \mathrm{w}$, respectively, while the overall highest yield was found in the water extract of flower $3.7 \% \mathrm{w} / \mathrm{w}$. Extraction with the solvents reflected that water has a higher percent of yield followed by chloroform with the three parts of the plant.

\section{Phytochemical profile}

Phytochemical screening revealed a wide range of phytochemicals that serves for the possible beneficial traits in the S. glauca. So far, many

Table 1: Extraction yield of bark, flowers, and leaves of Simarouba glauca with different solvents

\begin{tabular}{|c|c|c|c|c|}
\hline Sample & Surface & Color & Extraction yield $(\% \mathrm{w} / \mathrm{w})$ & Extraction \\
\hline $\mathrm{N} 1 \mathrm{~W}$ & Dry & Brown & 2.2 & Soxhlet \\
\hline N1M & Oily & Green & 0.6 & Soxhlet \\
\hline $\mathrm{N} 1 \mathrm{C}$ & Oily & Yellowish-brown & 2.4 & Soxhlet \\
\hline $\mathrm{N} 1 \mathrm{E}$ & Oily & Yellowish-brown & 1.6 & Soxhlet \\
\hline $\mathrm{N} 2 \mathrm{~W}$ & Dry & Brown & 3.7 & Soxhlet \\
\hline $\mathrm{N} 2 \mathrm{M}$ & Dry & Grey & 1.4 & Soxhlet \\
\hline $\mathrm{N} 2 \mathrm{C}$ & Oily & Black & 2.1 & Soxhlet \\
\hline N3W & Dry & Brown & 2.2 & Soxhlet \\
\hline N3M & Oily & Brown & 1.3 & Soxhlet \\
\hline N3C & Oily & Yellowish-brown & 2.7 & Soxhlet \\
\hline N3E & Oily & Yellowish-brown & 1.6 & Soxhlet \\
\hline
\end{tabular}

N1W: Water extract of bark, N1M: Methanol extract of bark, N1C: Chloroform extract of bark, N1E: Ethanol extract of bark. N2W: Water extract of flower, N2M: Methanol extract of flower, N2C: Chloroform extract of flower, N2E: Ethanol extract of flower, N3W: Water extract of leaves, N3M: Methanol extract of leaves, N3C: Chloroform extract of leaves and N3E: Ethanol extract of leaves 
researchers have reported the presence of alkaloids, tannins, terpenoids, anthraquinones, etc. In the present study, the phytochemicals detected in the samples are represented in Table 2. Water extract of S. glauca bark showed the presence of most of the phytochemicals, excluding steroids, terpenoids, and anthraquinones. Methanol extracts of the bark showed the presence of all phytochemicals, excluding flavonoids, steroids, and phenols. The chloroform extract of the bark showed the presence of flavonoids, carbohydrates, and oil. Ethanol extract of bark showed the presence of alkaloid, steroid, saponins, tannins, and oils. Water extract of flower showed alkaloids, phenols, and oil. However, the methanol extract of flowers indicated the absence of alkaloids, flavonoids, and terpenoids. Chloroform flower extracts showed absence of steroids, anthraquinones, and oil. Ethanol extract showed the presence of all the phytochemicals except carbohydrates. Water extract of leaves showed the presence of flavonoids, phenols and tannins. While its methanol extracts showed positive results for all the phytochemicals except flavonoids and terpenoids. The chloroform extract of leaves showed the absence of only steroids. Ethanol extracts of leaves showed the presence of all the phytochemicals analyzed except carbohydrates. Thus, from the phytochemical screening, it was evident that the bark and leaves extracts of S. glauca exhibited the maximum number of phytochemicals.

\section{Quantitative analysis of phytochemicals}

Alkaloid and flavonoid concentrations in the sample extracts were found to be high compared to phenols and carbohydrates. The chloroform extract of flower sample contained the highest amount of alkaloids $(2.1 \% \mathrm{w} / \mathrm{w})$ and flavonoid content was $(3.9 \% \mathrm{w} / \mathrm{w})$. Phenols and carbohydrates were found to be high in methanolic extracts of leaves sample $2.5 \% \mathrm{w} / \mathrm{w}$ and $2.2 \% \mathrm{w} / \mathrm{w}$, respectively, as shown in Table 3.

\section{Evaluation of antioxidant activity}

DPPH radical scavenging assay

The methanol and water extracts of S. glauca bark showed good radical scavenging activity through DPPH assay. Radical scavenger assay depends on the transfer of an electron to the stable free radical DPPH in the presence of the antioxidant. The number of electrons gained is related to a decrease in absorption [30]. The water extract of bark showed maximum scavenging of $80.39 \%$ while its methanol extract of showed $78.95 \%$ at $100 \mu \mathrm{g} / \mathrm{ml}$. The $\mathrm{IC}_{50}$ values of bark with water and methanol are $38.21 \mu \mathrm{g} / \mathrm{ml}$ and $56.14 \mu \mathrm{g} / \mathrm{ml}$, respectively. The chloroform extract of flowers showed maximum scavenging property $66.92 \%$, whereas the ethanol extract had $65.12 \%$ at $100 \mu \mathrm{g} / \mathrm{ml}$ of the sample extract and the $\mathrm{IC}_{50}$ values of are $40.62 \mu \mathrm{g} / \mathrm{ml}$ and $46.07 \mu \mathrm{g} / \mathrm{ml}$, respectively. In the leaves, maximum activity at $100 \mu \mathrm{g} / \mathrm{ml}$ was $71.14 \%$ for the ethanol extract and for methanol extract $63.32 \%$ and their $\mathrm{IC}_{50}$ values are $39.15 \mu \mathrm{g} / \mathrm{ml}$ and $40.40 \mu \mathrm{g} / \mathrm{ml}$, respectively. The results are shown in Figs. 1-3 and Table 4.

\section{Hydrogen peroxide scavenging assay}

Hydrogen peroxide is a weak oxidizing agent that has permeability to cell membranes and reacts with $\mathrm{Fe}^{2+}$ and $\mathrm{Cu}^{2+}$ to form hydroxyl radical which leads to cytotoxic effects. Furthermore, hydrogen peroxide possesses the ability to inactivate the thiol (-SH) group in enzymes [31]. The hydrogen peroxide scavenging activity conducted for the sample extracts showed dose-dependent response. Thus, maximum activity was observed at $100 \mu \mathrm{g} / \mathrm{ml}$ (Figs. 4-6). Methanol and water extracts of S. glauca bark showed $88.57 \%$ and $90.91 \%$ scavenging activity, respectively, their corresponding $\mathrm{IC}_{50}$ values are 66.46 and $39.63 \mathrm{microgram} / \mathrm{ml}$. Chloroform and ethanol extracts of the flower showed lesser scavenging activity of $69.00 \%$ and $66.07 \%$, respectively, at $100 \mu \mathrm{g} / \mathrm{ml}$, where their IC $_{50}$ values were found to be $47.36 \mu \mathrm{g} / \mathrm{ml}$ for chloroform and for ethanol $54.52 \mu \mathrm{g} / \mathrm{ml}$. Ethanol and methanol extracts of the leaves showed maximum scavenging property of $75.85 \%$ and $63.13 \%$, respectively, at $100 \mu \mathrm{g} / \mathrm{ml}$, while their corresponding $\mathrm{IC}_{50}$ values were observed to be $44.17 \mu \mathrm{g} / \mathrm{ml}$ and $48.29 \mu \mathrm{g} / \mathrm{ml}$ (Table 4 ).

\section{Reducing power assay}

The reducing power is a measure of an antioxidant to donate electrons to the free radicals generated and cause neutralization. The reducing power of depends on the ability of the extracts to reduce ferric cyanide $\mathrm{Fe}^{3+}$ to ferrocyanide $\mathrm{Fe}^{2+}$ by donating an electron [32]. The results showed that the highest reducing activity is exerted in the bark extracts. The methanol and water extracts of S. glauca bark showed $77.72 \%$ and $79.25 \%$ reducing activity at $100 \mu \mathrm{g} / \mathrm{ml}$ extract concentration, respectively. The maximum reducing capacity of flower extracts of

Table 2: Phytochemical constituents of Simarouba glauca extracts

\begin{tabular}{|c|c|c|c|c|c|c|c|c|c|c|}
\hline Sample & Alkaloids & Flavonoids & Steroids & Terpenoids & Anthraquinone & Phenols & Saponins & Tannins & Carbo hydrates & Oil \\
\hline $\mathrm{N} 1 \mathrm{~W}$ & + & + & - & - & - & + & + & + & + & + \\
\hline $\mathrm{N} 1 \mathrm{M}$ & + & - & - & + & + & - & & + & + & + \\
\hline $\mathrm{N} 1 \mathrm{C}$ & - & + & & - & & - & - & & + & + \\
\hline $\mathrm{N} 1 \mathrm{E}$ & + & - & + & - & & - & + & + & - & + \\
\hline $\mathrm{N} 2 \mathrm{~W}$ & + & - & - & - & - & + & - & - & - & + \\
\hline $\mathrm{N} 2 \mathrm{M}$ & - & - & + & - & + & + & & + & + & + \\
\hline $\mathrm{N} 2 \mathrm{C}$ & + & - & - & + & - & & + & & + & - \\
\hline N3W & - & + & - & - & - & + & - & + & - & - \\
\hline N3M & + & - & & - & + & + & + & + & + & + \\
\hline N3C & + & + & - & + & & & & & + & + \\
\hline N3E & + & + & + & + & & + & & + & - & + \\
\hline
\end{tabular}

“+" means positive, "-" means negative and blank indicates slightly positive/negative). N1W: Water extract of bark, N1M: Methanol extract of bark, N1C: Chloroform extract of bark, N1E: Ethanol extract of bark. N2W: Water extract of flower, N2M: Methanol extract of flower, N2C: Chloroform extract of flower and N2E: Ethanol extract of flower. N3W: Water extract of leaves, N3M: Methanol extract of leaves, N3C: Chloroform extract of leaves, N3E: Ethanol extract of leaves

Table 3: Quantitative phytochemicals analysis of sample extracts

\begin{tabular}{|c|c|c|c|c|}
\hline Sample & Alkaloids (w/w) & Flavonoids (w/w) & Phenols (w/w) & Carbohydrates (w/w) \\
\hline $\mathrm{N} 1 \mathrm{~W}$ & 1.1 & 3.1 & 0.3 & 1.9 \\
\hline $\mathrm{N} 1 \mathrm{M}$ & 1.7 & Absent & Absent & 1.6 \\
\hline $\mathrm{N} 2 \mathrm{C}$ & 2.1 & 3.9 & Absent & 1.5 \\
\hline N2E & 1.4 & 2.2 & 2.2 & Absent \\
\hline N3M & 1.2 & Absent & 2.5 & 2.2 \\
\hline N3E & 0.8 & 1.5 & 1.8 & Absent \\
\hline
\end{tabular}

N1W: Water extract of bark, N1M: Methanol extract of bark. N2C: Chloroform extract of flower, N2E: Ethanol extract of flower. N3M: Methanol extract of leaves,

N3E: Ethanol extract of leaves 


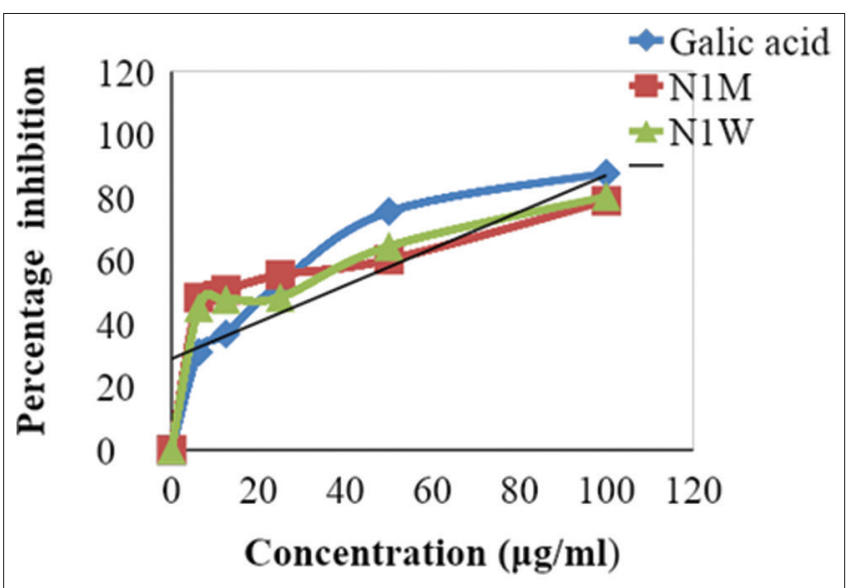

Fig. 1: 2,2-Diphenyl-1-picrylhydrazyl radical scavenging activity of bark extracts of Simarouba glauca

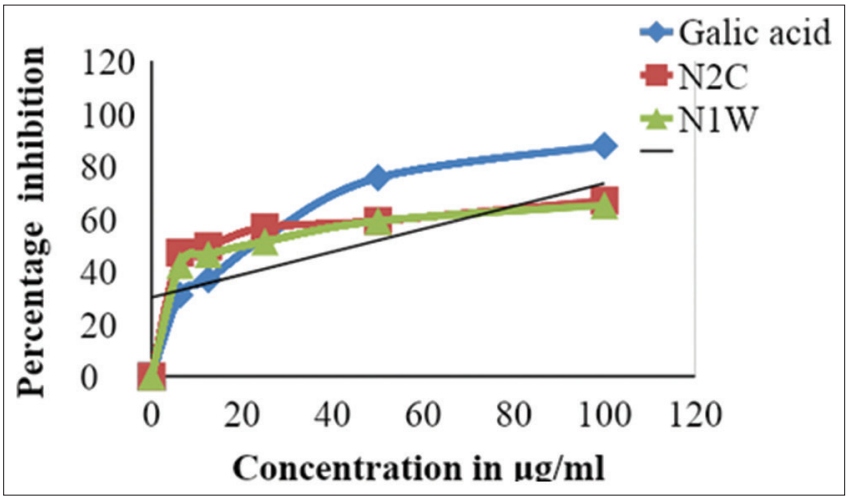

Fig. 2: 2,2-Diphenyl-1-picrylhydrazyl radical scavenging activity of flowers extracts of Simarouba glauca

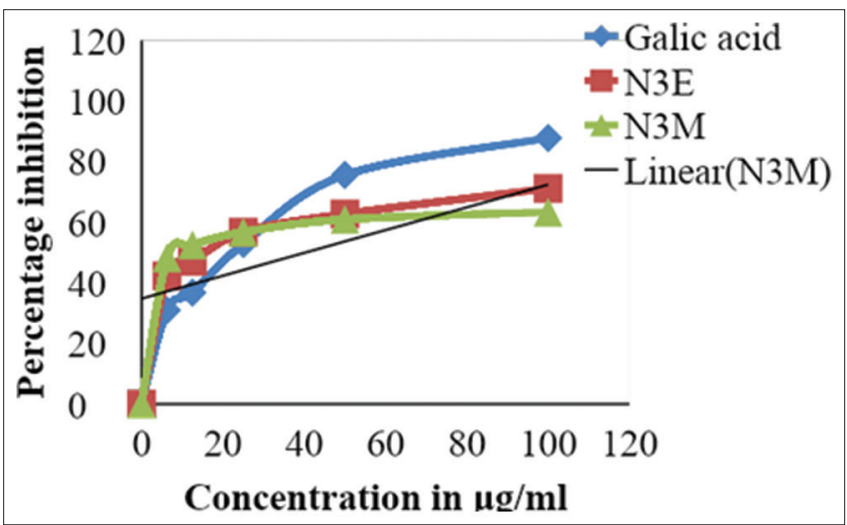

Fig. 3: 2,2-Diphenyl-1-picrylhydrazyl radical scavenging activity of leaves extracts of Simarouba glauca

chloroform and ethanol was observed to be $64.98 \%$ and $63.07 \%$, respectively, at $100 \mu \mathrm{g} / \mathrm{ml}$. The ethanol and methanol extracts of leaves showed the activity of $79.44 \%$ and $61.16 \%$, respectively, and their corresponding $\mathrm{IC}_{50}$ values are $43.50 \mu \mathrm{g} / \mathrm{ml}$ and $46.33 \mu \mathrm{g} / \mathrm{ml}$ (Table 4). Results are represented in Fig. 7-9.

NO radical scavenging assay

NO is a reactive free radical produced by the endothelial cells and phagocytes that yield more reactive species such as peroxynitrite which can be decomposed to form $\mathrm{OH}$ radicals. The assay reflected the potential of the plant extracts to suppress the NO released since NO plays a very important role in the pathogenesis of inflammation [33].

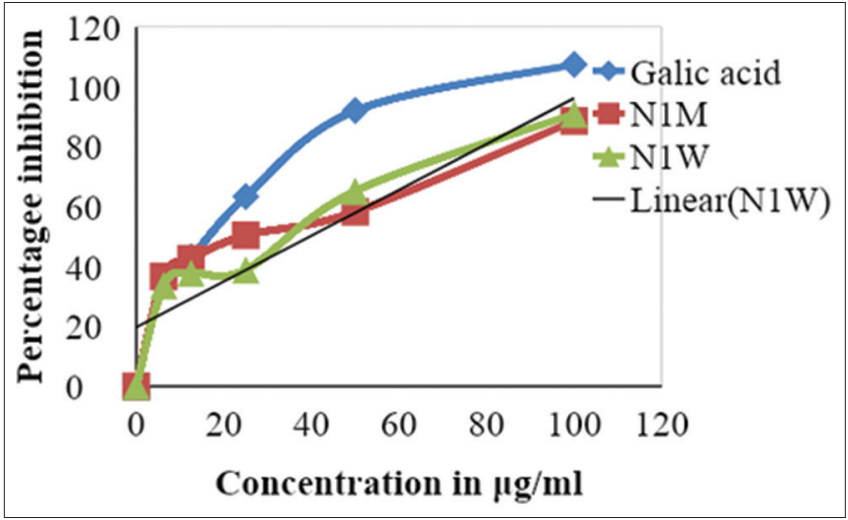

Fig. 4: Hydrogen peroxide radical scavenging activity of bark extract of Simarouba glauca

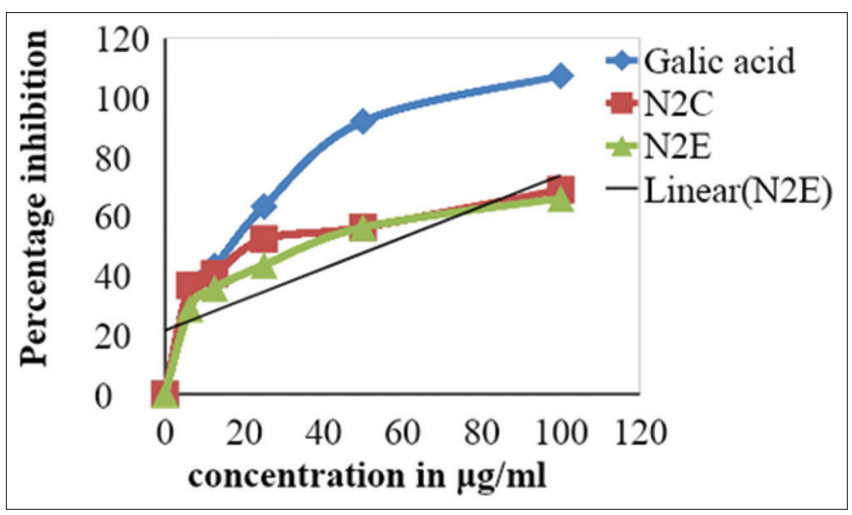

Fig. 5: Hydrogen peroxide radical scavenging activity of flowers extract of Simarouba glauca

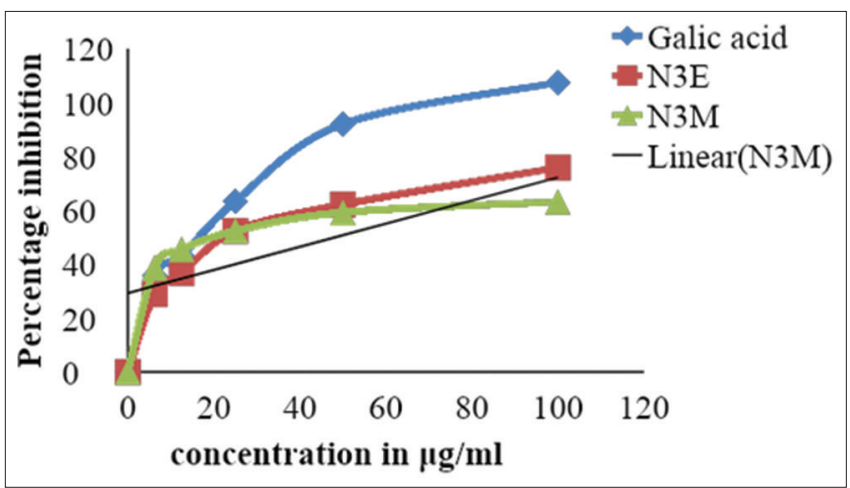

Fig. 6: Hydrogen peroxide radical scavenging activity of leaves extract of Simarouba glauca

The assay results of the extracts were compared with the ascorbic acid taken as standard. NO radical scavenging assay showed dose-dependent inhibition; the results are shown in Fig. 10-12 and Table 4. The highest inhibitory activity was observed in the water extract of bark $79.08 \%$ at a concentration of $100 \mu \mathrm{g} / \mathrm{ml}$ with $49.12 \mu \mathrm{g} / \mathrm{ml} \mathrm{IC}_{50}$ value. Ethanol and chloroform extracts of flowers showed inhibition of nearly $67.0 \%$ at concentration $100 \mu \mathrm{g} / \mathrm{ml}$. The inhibitions exerted by ethanol and methanol extracts of leaves are $77.31 \%$ and $56.01 \%$, respectively.

\section{DISCUSSION}

Plants are the source of phytochemicals which are found to be bioactive compounds. The plants develop defense mechanism against predators such as insects, herbivores, and microorganisms by producing phytochemicals as secondary metabolites [34]. The 
Table 4: Maximum percentage of radical scavenging activity at $100 \mu \mathrm{g} / \mathrm{ml}$ and their respective $\mathrm{IC}_{50}$ values of the bark, flowers, and leaves with different solvents

\begin{tabular}{|c|c|c|c|c|c|c|c|c|}
\hline \multirow[t]{2}{*}{ Sample } & \multicolumn{2}{|l|}{ DPPH } & \multicolumn{2}{|l|}{$\mathbf{H}_{2} \mathbf{O}_{2}$} & \multicolumn{2}{|c|}{ Reducing power } & \multicolumn{2}{|l|}{ NO } \\
\hline & $\%$ Inhibition & $\mathrm{IC}_{50}(\mu \mathrm{g} / \mathrm{ml})$ & $\%$ Inhibition & $\mathrm{IC}_{50}(\mu \mathrm{g} / \mathrm{ml})$ & \% Inhibition & $\mathrm{IC}_{50}(\mu \mathrm{g} / \mathrm{ml})$ & $\%$ Inhibition & $\mathrm{IC}_{50}(\mu \mathrm{g} / \mathrm{ml})$ \\
\hline Gallic acid & 87.79 & 35.30 & 107.43 & 24.56 & 86.64 & 40.39 & - & - \\
\hline Ascorbic acid & - & - & - & - & - & - & 92.02 & 38.41 \\
\hline $\mathrm{N} 1 \mathrm{M}$ & 78.95 & 56.14 & 88.57 & 66.46 & 77.72 & 62.18 & 59.15 & 58.96 \\
\hline $\mathrm{N} 1 \mathrm{~W}$ & 80.39 & 38.21 & 90.92 & 39.63 & 79.25 & 39.76 & 79.08 & 49.12 \\
\hline $\mathrm{N} 2 \mathrm{C}$ & 66.92 & 40.62 & 69.00 & 47.36 & 64.98 & 45.84 & 67.01 & 52.71 \\
\hline N2E & 65.12 & 46.07 & 66.07 & 54.52 & 63.07 & 51.41 & 67.02 & 52.67 \\
\hline N3E & 71.14 & 39.15 & 75.85 & 44.17 & 79.44 & 43.50 & 77.31 & 50.92 \\
\hline N3M & 63.32 & 40.40 & 63.13 & 48.29 & 61.16 & 46.33 & 56.01 & 62.96 \\
\hline
\end{tabular}

N1M: Methanol extract of bark, N1W: Water extract of bark, N2C: Chloroform extract of flower, N2E: Ethanol extract of flower, N3E: Ethanol extract of leaves and N3M: Methanol extract of leaves. DPPH: 2,2-Diphenyl-1-picrylhydrazyl, NO: Nitric oxide

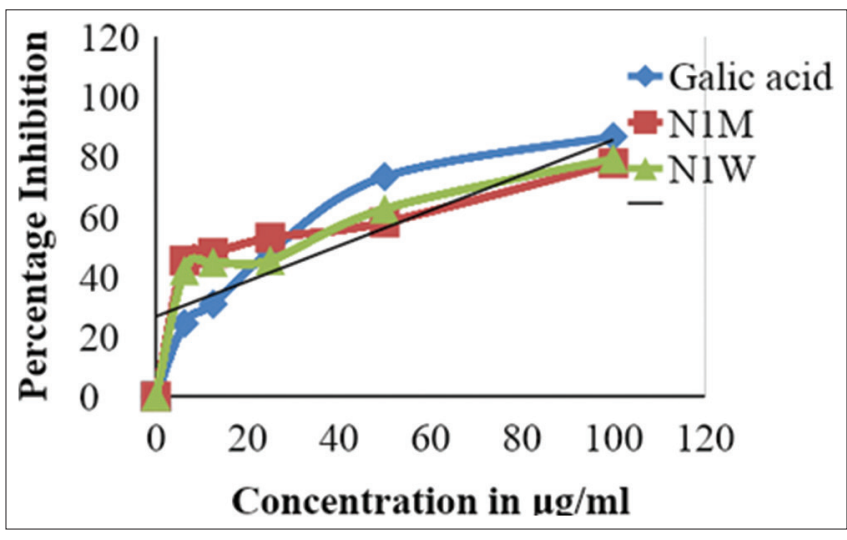

Fig. 7: Reducing the power of bark extracts of Simarouba glauca

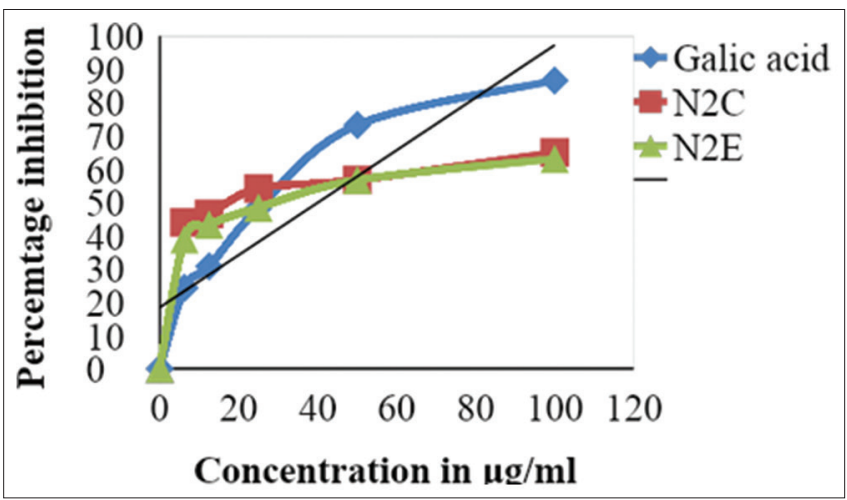

Fig. 8: Reducing the power of flower extracts of Simarouba glauca

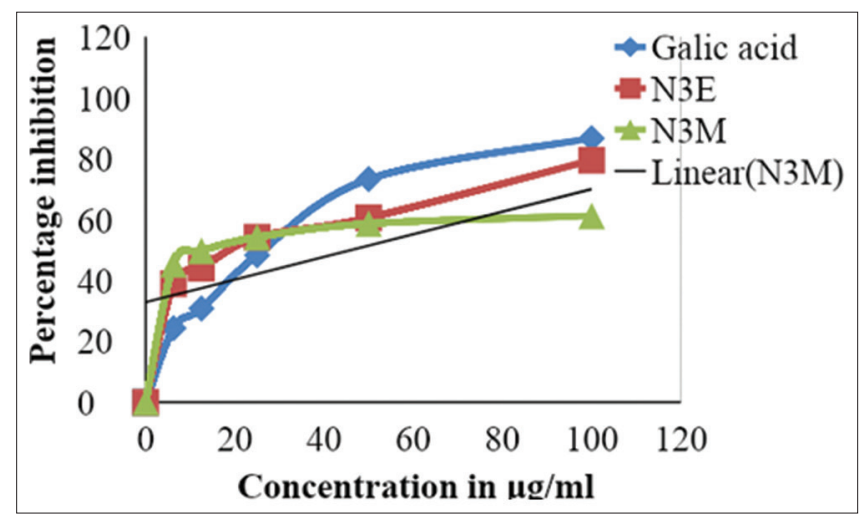

Fig. 9: Reducing the power of leaves extracts of Simarouba glauca

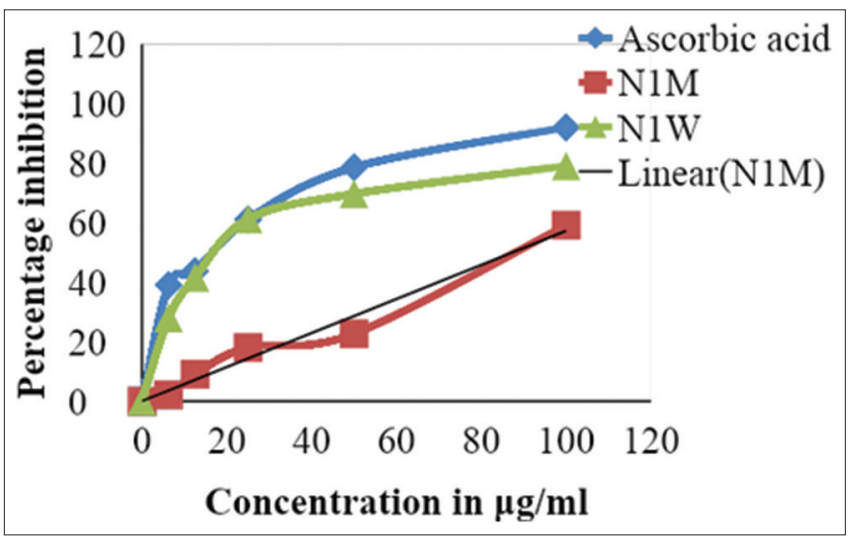

Fig. 10: Nitric oxide scavenging activity of bark extracts of Simarouba glauca

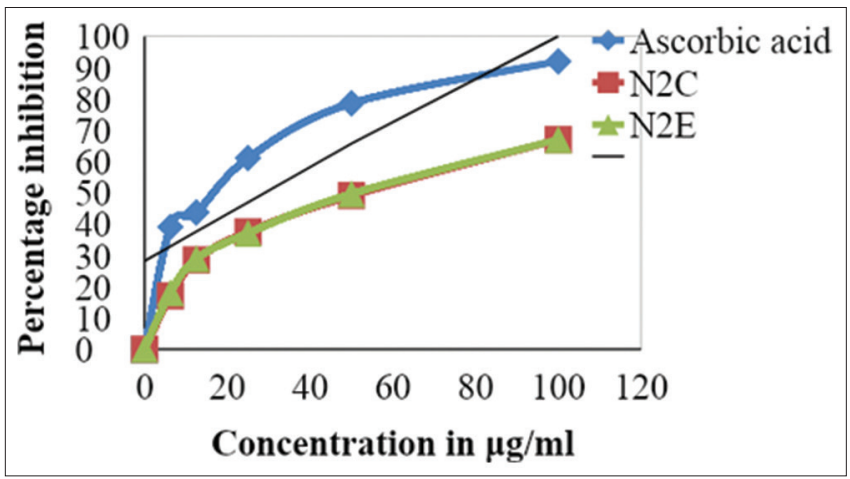

Fig. 11: Nitric oxide scavenging activity of flower extracts of Simarouba glauca

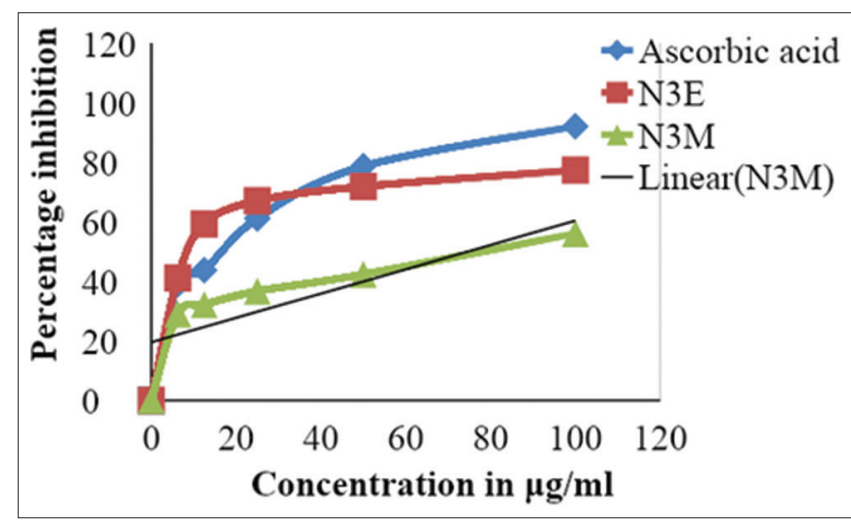

Fig. 12: Nitric oxide scavenging activity of leaves extracts of Simarouba glauca 
secondary metabolites include the alkaloids, terpenoids, flavonoids, saponins, tannins, and phenols. These compounds are explored for the treatment of many diseases in humans. The quality of phytochemicals is evaluated with its antioxidant capacity [35]. The present research was to investigate and compare the phytochemical constituents and to study the antioxidant activity of bark, flower, and leaves of S. glauca. To justify this plant for the medicinal properties it possesses; therefore, it is necessary to evaluate the phytochemical constituents of the plant. Flavonoids and polyphenols are commonly considered as potent antioxidants [36]. The dry powder of bark, flowers, and leaves was subjected to solvent extraction using ethanol, chloroform, methanol, and water. The phytochemical screening showed wide range of the secondary metabolites in these extracts. The results obtained from the phytochemical profiling confirmed the presence of alkaloids, flavonoids, and phenols in the water extract of bark and ethanol extract of flower and leaves. The highest percentage yield was obtained in the water extract of flowers, and the least was found in methanol extract of bark. Quantification of total carbohydrate, phenol, alkaloid, and flavonoid content revealed the presence of high concentration of alkaloid and flavonoid in the chloroform extract of the flower. The effectiveness of phytochemicals in its pure form or a mixture is measured by the antioxidant activity [37]. The antioxidant activity was evaluated by different assays, in methanol and water extract of bark, chloroform and ethanol extract of flowers, and ethanol and methanol extract of leaves. The antioxidant activity of these extracts was measured using the assays: DPPH, hydrogen peroxide, reducing power, and NO. Researchers in the past have explored the phytochemical constituents and antioxidant activity in the leaf extracts of S. glauca [38-40]. The in vitro studies have further demonstrated the physiological properties of the leaf extract [39]. Anticancer activity of the leaf extract has been shown in the bladder cell lines [40]. A recent study has reported the phytochemical constituents and the antioxidant activity in the root bark [41]. There are no reports on the comparative study of phytochemicals and antioxidant activity of flowers with respect to leaves and bark. The results obtained from the radical scavenging assays revealed that the aqueous extract of bark had maximum scavenging activity irrespective of the solvent used, except for the reducing power. The reducing power of the ethanol extract of leaves was recorded maximum.

\section{CONCLUSION}

The results of this study conclude that the bark, flower, and leaves possess the phytoconstituents which is responsible for their active therapeutic properties. Alkaloids, flavonoids, terpenoids, tannins, saponins, steroids, etc., present in any of the bark, flower or leave extracts, suggested a successful qualitative analysis. Antioxidant properties estimated using DPPH, hydrogen peroxide, reducing power, and NO scavenging assays exerted the potent antioxidant property in extracts of bark, flower, and leaves of $S$. glauca. Hence, this plant is a potent source of antioxidant, supporting its medicinal use. The comparative investigation the bark, flowers, and leaves of this plant revealed that the bark has maximum percentage of scavenging activity. Therefore, bark is a better resource antioxidant than flowers and leaves. However, further research through in vivo studies on the ability of the bark to act as an antioxidant is essential to comprehend its use in the pharmaceutical industry. The bark can be exploited for the isolation of bioactive compounds having pharmaceutical importance. This can lead to the development of safe drugs against many chronic diseases developed due to oxidative damage.

\section{ACKNOWLEDGMENTS}

Authors are grateful to Government Science College (Autonomous), Bengaluru, for the instrumental facility which is procured under DSTFIST (SR-FT/College-272) program.

\section{AUTHORS' CONTRIBUTIONS}

Sajeeda and Shivakumar collected the plant sample and performed the phytochemical estimation and antioxidant study. Kolgi and Shivaraj have carried out extraction and phytochemical screening. CS Karigar contributed to the research guidance and coordinated the manuscript writing, editing, and finalization. All authors read and approved the final manuscript.

\section{CONFLICTS OF INTEREST}

Authors declare that they have no conflicts of interest.

\section{REFERENCES}

1. Govindaraju K, Darukeshwara J, Srivastava AK. Studies on protein characteristics and toxic constituents of Simarouba glauca oilseed meal. Food Chem Toxicol 2009;47:1327-32.

2. Joshi S, Joshi S. Oil Tree Laxmitaru glauca. New Delhi, India: University of Agricultural Sciences, Bangalore and ICAR; 2002. p. 86.

3. Alves AB, Miranda HM, Luiz AL, Karina P, Randaua B. Simaroubaceae family: Botany, chemical composition and biological activities. Rev Bras Farmacogn 2014;24:481-501.

4. Patil MS, Gaikwad DK. A critical review on medicinally important oil yielding plant Laxmitaru (Simarouba glauca DC). J Pharm Sci Res 2011;3:1195-213.

5. Gilman EF, Watson DG. Simarouba glauca: Young Paradise-Tree. Fact Sheet, No. ST-590; 1994.

6. Jancy VS, Rajamani, Betty D. Antimicrobial Effect of Simarouba glauca (Lakshmi Taru) on opportunistic pathogens in HIV/AIDS patients. IOSR J Pharm Biol Sci 2016;11:32-9.

7. Ham EA, Schafer HM, Denkewalter RG, Brink NG. Structural studies on glaucarubin from Simarouba glauca. J Am Chem Soc 1954;76:6066-8

8. Kupchan SM, Britton RW, Lacadie JA, Ziegler MF, Sigel CW. Isolation and structural elucidation of bruceantin and bruceantinol, new potent antileukemic quassinoids from Brucea antidysenterica. J Org Chem 1975;40:648-54

9. Franssen FF, Smeijsters LJ, Berger I, Medinilla Aldana BE. In vivo and in vitro antiplasmodial activities of some plants traditionally used in Guatemala against malaria. Antimicrob Agents Chemother 1997;41:1500-3

10. Valeriote FA, Corbett TH, Grieco PA, Moher ED, Collins JL, Fleck TJ, et al. Anticancer activity of glaucarubinone analogues. Oncol Res 1998;10:201-8.

11. Cáceres A, López B, González S, Berger I, Tada I, Maki J, et al. Plants used in Guatemala for the treatment of protozoal infections. I. Screening of activity to bacteria, fungi and American trypanosomes of 13 native plants. J Ethnopharmacol 1998;62:195-202.

12. Kupchan SM, Lacadie JA, Howie GA, Sickles BR. Structural requirements for biological activity among antileukemic glaucarubolone ester quassinoids. J Med Chem 1976;19:1130-3

13. Monseur X, Motte JC. High-performance liquid chromatographic analysis of bitter quasinoid compounds from $S$. glauca. J Chromatogr 1983;264:469-73.

14. Nurhanan MY, Azimahtol H, Ilham M, Shukri MA. Cytotoxic effects of root extracts of Eurycoma longifolia. J Phytother Res 2005;19:994-6.

15. Fukamiya N, Lee KH, Muhammad I, Murakami C, Okano M, Harvey I, et al. Structure-activity relationships of quassinoids for eukaryotic protein synthesis. Cancer Lett 2005;220:37-48.

16. Damintoti K, Dicko MH, Simpore J, Traore A. Antioxidant and antibacterial activities of polyphenols from ethnomedicinal plants of Burkina Faso. Afr J Biotechnol 2005;4:823-8.

17. Goyal AK, Middha SK, Sen A. Evaluation of DPPH radical scavenging activity, total phenols and antioxidant activities in Indian wild Bambusa vulgaris "Vittata" methanolic leaf extract. J Nat Pharm 2010;1:40-5

18. Harborne JB. Phytochemical Methods. A Guide to Modern Techniques of Plant Analysis. London: Chapman and Hall; 1973.

19. Renuka K, Vellai RD, Sorimuthu PS. Phytochemical screening and in vitro evaluation of antioxidant potential of immature Palmyra palm (Borassus flabellifer Linn) fruits. Int J Pharm Pharm Sci 2018;10:77-83.

20. Hussain I, Moneeb UR, Riaz U, Zia M, Naeem K, Farhat AK, et al. Phytochemicals screening and antimicrobial activities of selected medicinal plants of Khyber-pakhtunkhwa, Pakistan. Afr J Pharm Pharmacol 2011;5:746-50.

21. Obodoni BO, Ochuko PO. Phytochemical studies and comparative efficacy of the crude extracts of some Homostatic plants in Edo and Delta States of Nigeria. Glob J Pure Appl Sci 2001;8:203-8.

22. Neeru A, Divya KM, Khushboo R. Estimation of total carbohydrate present in dry fruits. IOSR J Envi Sci Toxicol Food Technol 2015;1:24-7. 
23. Jayakumari S, Anbu J, Ravichandiran V, Ashwini A, Sivakumar GM, Singh M. Antiulcergenic and free radical scavenging activity of flavonoid fraction of Psidium guajava Linn leaves. Int J Pharm Pharm Sci 2012;4:170-4.

24. Kamala A, Middha SK, Gopinath C, Sindhura HS, Karigar CS. In vitro antioxidant potentials of Cyperus rotundus L. Rhizome extracts and their phytochemical analysis. Pharmacogn Mag 2018;14:261-7.

25. Rajamanikandan S, Sindhu T, Durgapriya D, Sophia D, Ragavendran P, Gopalakrishnan VK. Radical scavenging and antioxidant activity of ethanolic extract of Mollugo nudicaulis by in vitro assays. Ind J Pharm Educ Res 2011;45:310-6.

26. Nishaa S, Vishnupriya M, Sasikumar JM, Christabel HP, Gopalkrishnan VK. Antioxidant activity of ethanolic extract of Maranta arundinacea. L. tuberous rhizomes. Asian J Pharm Clin Res 2012;5:85-8

27. Zerargui F, Baghiani A, Khennouf S, Arrar L. Antiosidant acticity assessment of Tamus communis L. roots. Int J Pharm Pharm Sci 2016;8:64-71.

28. Kumar S, Kumar D, Manjusha, Saroha K, Singh N, Vashishta B. Antioxidant and free radical scavenging potential of Citrullus colocynthis (L.) Schrad. methanolic fruit extract. Acta Pharm 2008;58:215-20.

29. Dharmendra S, Manish M, Monika G, Poonam S, Abhishek G, Rajeev N. Nitric oxide radical scavenging assay of bioactive compounds present in methanol extract of Centella asiatica. Int J Pharm Pharm Sci Res $2012 ; 2: 42-4$

30. Silva CG, Herdeiro RS, Mathias CJ, Panek AD, Silveira CS, Rodrigues VP, et al. Evaluation of antioxidant activity of Brazilian plants. Pharmacol Res 2005;52:229-33.

31. Kumaran A, Karunakaran RJ. In vitro antioxidant activities of methanol extract of Phyllanthus species from India. LWT Food Sci Tech 2007; 40:344-52

32. Yen GC, Chen HY. Antioxidant activity of various tea extracts in relation to their antimutagenicity. J Agric Food Chem 1995;43:27-32.
33. Hagerman AE, Riedl KM, Jones GA, Sovik KN, Ritchard NT, Hartzfeld PW, et al. High molecular weight plant polyphenolics(Tannins) as biological antioxidants. J Agric Food Chem 1998;46:1887-92.

34. Britto JD, Sebastian SR. Biosynthesis of silver nanoparticles and its antibacterial activity against human pathogens. Int J Pharm Sci 2011;5:257-59

35. Zheng W, Wang SY. Antioxidant activity and phenolic compounds in selected herbs. J Agric Food Chem 2001;11:5165-70

36. Iqbal E, Salim KA, Lim LB. Phytochemical screening, total phenolics and antioxidant activities of bark and leaf extracts of Goniothalamus velutinus (Airy Shaw) from Brunei Darussalam. J King Saud Univ Sci 2015;27:224-32.

37. Vinson JA, Zhang J. Black and green teas equally inhibit diabetic cataracts in a streptozotocin-induced rat model of diabetes. J Agric Food Chem 2005;53:3710-3.

38. Osagie-Eweka SE, Noghayin JO, Diamond OE. Comparative phytochemical analyses and in-vitro antioxidant activity of aqueous and ethanol extracts of Simarouba glauca (Paradise Tree). Euro J Med Plants 2016;13:1-11.

39. Santhana L, Sangeetha D, Sivamani S, Tamilarasan M, Rajesh TP, Anandraj B. In vitro antibacterial, antioxidant, haemolytic, thrombolytic activities and phytochemical analysis of Simarouba glauca leaves extracts. Int J Pharm Sci Res 2014;5:432-7.

40. Sridevi IP, Shridhar CG, Rajendra BN, Sunil SJ, Murigendra BH. Evaluation of in-vitro antioxidant and anticancer activity of Simarouba glauca leaf extracts on T-24 bladder cancer cell line. Pharm J 2017;9:906-12

41. Osagie-Eweka SE, Okosun ME. Phytochemical identification and comparative in-vitro antioxidant studies on aqueous, ethanol and methanol root bark extract of Simarouba glauca. Eur J Med Plants 2019;26:1-10 